\title{
INFLUENGE OF DENDOMETRIC AND MORPHOLOGICAL CHARACTERISTICS ON STEMFLOW IN A FOREST-SAVANNA TRANSITION AREA IN THE BRAZILIAN AMAZON
}

\author{
Balieiro RMF ${ }^{1}$, Tonello $\mathrm{KC}^{2}$, da Costa Neto $\mathrm{SV}^{3} \&$ Bramorski J ${ }^{4,}$ * \\ ${ }^{1}$ Department of Environment and Development, Federal University of Amapá, Rod Juscelino Kubitschek, km 02 - Jardim \\ Marco Zero, Macapá - AP, 68903-419 Brazil \\ ${ }^{2}$ Federal University of São Carlos, Campus Sorocaba - SP, Rod João Leme dos Santos, km 110 - SP-264 Bairro do Itinga - \\ Sorocaba CEP 18052-780 Brazil \\ ${ }^{3}$ Institute of Scientific and Technological Research of the State of Amapá - AP, Av Feliciano Coelho, 1509 - Trem, Macapá \\ - AP, 68901-025 Brazil \\ ${ }^{4}$ Department of Environment and Development, Federal University of Amapá, Rod Juscelino Kubitschek, km 02 - Jardim \\ Marco Zero, Macapá - AP, 68903-419 Brazil \\ *bramorski@gmail.com
}

Submitted September 2020; accepted December 2020

\begin{abstract}
Species-specific morphological characteristics play a decisive role in determining stemflow. However, in tropical forests, as a result of high biodiversity, the results can be conflicting. The objective of this study was to analyse the influence of tree morphology on water running down tree trunks in a forest-savanna transition area in the Brazillian Amazon. A total of 46 trees were installed samplers for stemflow monitoring. Rainfall events with a volume of $>10 \mathrm{~mm}$ were recorded. Dendometric variables and morphological characteristics of the trees were related to the stemflow volume. Circumference at breast height, basal area and canopy projection area were determinants for the formation of distinct tree groups, whereas these variables were not significantly correlated with stemflow volume. When the trees were grouped according to their morphological characteristics, significant correlations were identified for basal area and circumference at breast height for stemflow from trees with an upright trunk and rough bark. Mean stemflow volume from trees with a smooth bark was higher than the other trees. However, when the variable trunk inclination was inserted, the mean stemflow from upright trunks was lowest and that from inclined trunks was highest, showing the relevance of this variable for stemflow production.
\end{abstract}

Keywords: Tree morphology, trunk inclination, trunk roughness, forest hydrology, tropical forest

\section{INTRODUCTION}

Forests represent an important interface between the atmosphere and land surface, and can interact with/alter/influence/modify rainwater interception by the canopy (Munishi \& Shear 2005, Frost \& Levia 2014). In hydrological studies of forest ecosystems, it is essential to determine the precipitation volume partitioned by the canopy, by separating the intercepted fraction, the fraction that passes freely through the canopy (throughfall) and the fraction that flows off down the trunk (stemflow) (Giglio \& Kobiyama 2013, Metzger et al. 2019). Interception represents the water evaporated from the canopy, whereas throughfall and stemflow represent fractions of the water entries into the system. Throughfall passes directly through canopy openings or is released as drops or splashes from the canopy surfaces, while stemflow is the part of the intercepted water that runs slowly down tree trunks into the forest soil (Zhang et al. 2013, Carlyle-Moses et al. 2018).

Despite representing a minor fraction of the total precipitation, stemflow is essential for hydrological functioning of ecosystems (Staelens et al. 2008, Levia \& Germer 2015). It is a concentrated point source of water and nutrients that transports solutes (i.e. ions leached from tree structures) from the canopy to the forest soil (Burbano Garcés et al. 2014, Cayuela et al. 2018).

The process of stemflow production involves complex interactions between multiple biotic and abiotic factors (Van Stan \& Levia 2009, Van Stan \& Friesen 2020). It is therefore difficult to quantify these separate factors but morphological 
characteristics of tree species play an important role in determining the amount of water flowing down the trunk (Van Stan \& Levia 2009). Stemflow volume differs between species due to differences in bark texture and tree size (Levia et al. 2010). Variability in stemflow production has also been contributed to contrasting biophysical characteristics among tree species, such as canopy size, leaf shape and orientation, branch angle and bark roughness (Van Stan \& Levia 2009, Van Stan et al. 2016) .

Although these relationships are welldocumented for temperate forests, conflicting results have been observed in the tropics (Marin et al. 2000). Information about interspecific variations in stemflow production of tree species is important for plant/tree survival during dry periods (Yang et al. 2018).

Water balance of the Amazon forest, which sustains the highly diverse biome, is indispensable for the local, regional and global climate regulation (Nobre 2014), although little is known about the hydrological cycle (Nobre et al. 2004). The study of water-forest interaction for soil conservation and management is more important now especially for recovering degraded areas and combating deforestation. Therefore, the objective of the study was to analyse the influence of tree morphology on stemflow of forest species in the forest-savanna transition area of the Brazilian Amazon.

\section{MATERIALS AND METHODS}

\section{Study location}

The study was carried out in a fragment of the Terra Firme (upland rainforest) in the Amazon region, in a forest-savanna transition area, of the Federal University of Amapá, Campus Marco Zero, known as Mata do Sussurro (Figure 1). The State of Amapá has a super humid equatorial climate, with temperatures of around $27^{\circ} \mathrm{C}$. Mean annual rainfall at the coastal region of the capital Macapá is $3250 \mathrm{~mm}$ and practically $90 \%$ of the annual rain volume falls between December and July (Drummond 2004).

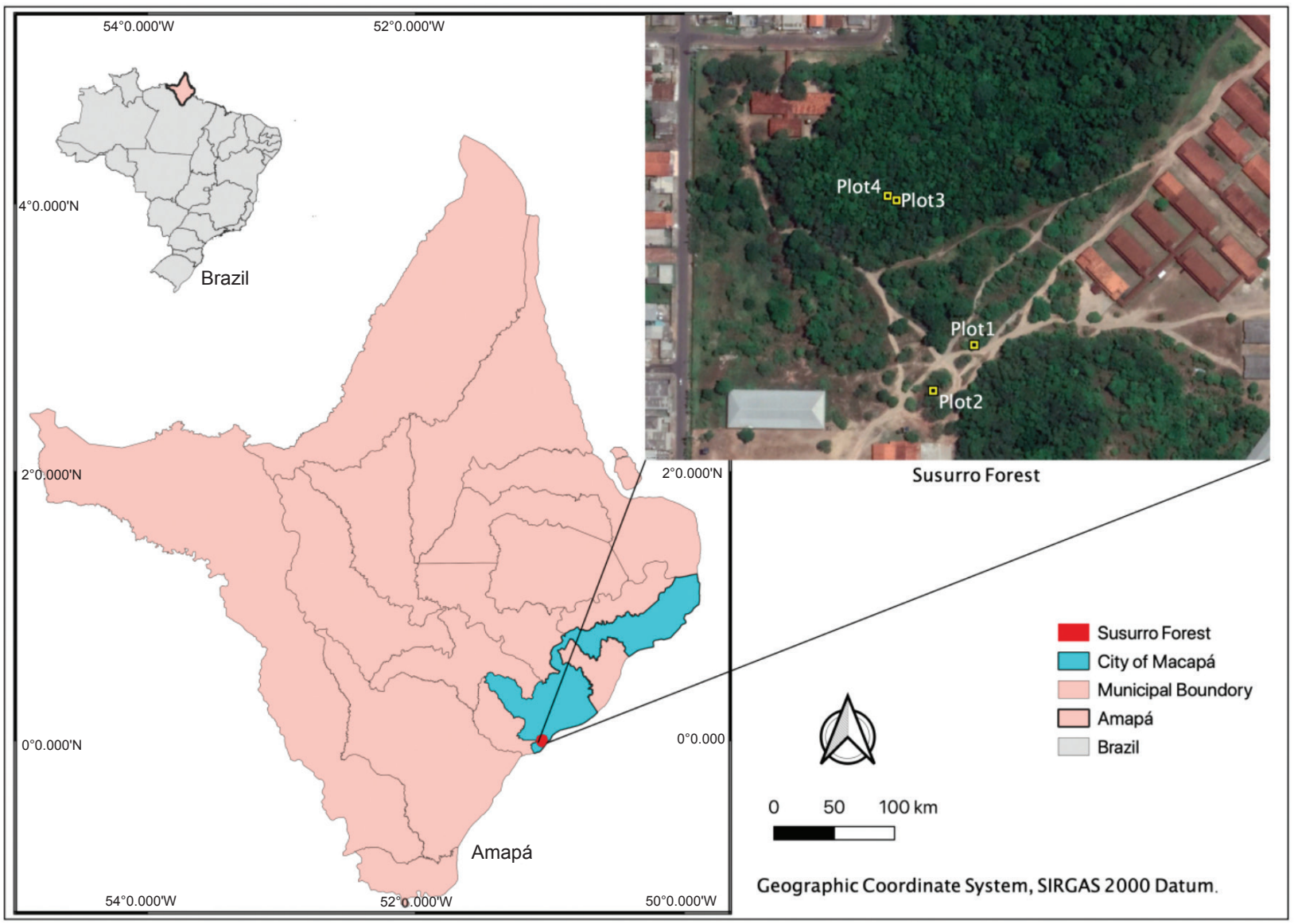

Figure 1 Location of the study area in a forest-savanna transition area at the Terra Firme, Amazon region 


\section{Experimental design}

\section{Plot description}

Four plots were installed, where plots 1 and 2 (Figures 2a and b) were located at the edge of the forest fragment and plots 3 and 4 (Figures 2c and $\mathrm{d}$ ), within the fragment. The characteristics of each plot are shown in Table 1 .

\section{Dendometric characterisation}

Trees with a circumference at breast height $(\mathrm{CBH})$ of $>15 \mathrm{~cm}$ were measured for tree height, basal area and canopy projection area.

The basal area (BA) was calculated by the equation:
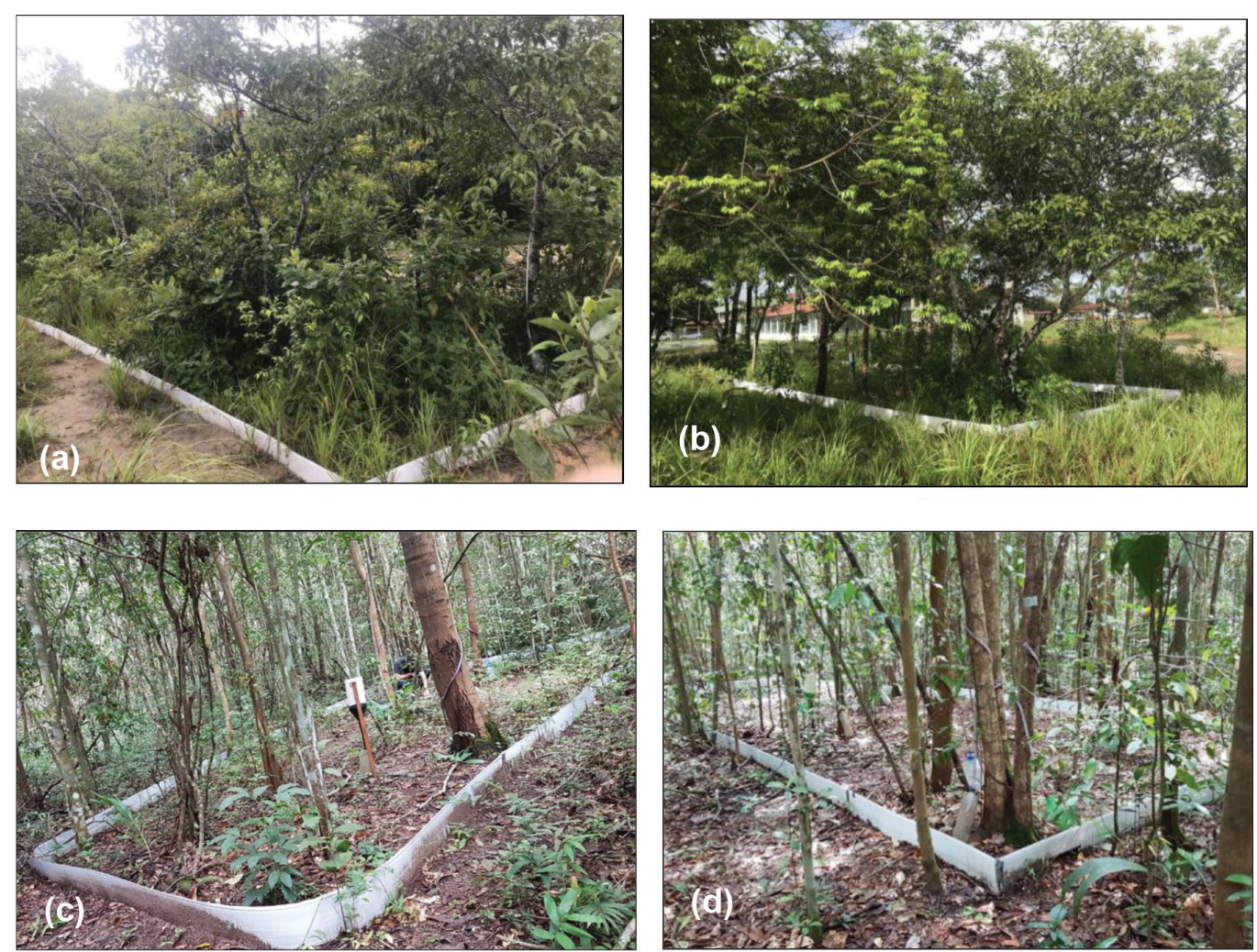

where, $\mathrm{DBHi}=$ individual diameter at breast height $(\mathrm{DBH})$ of a tree $\left(\mathrm{cm}^{2}\right)$, calculated as follows:

$$
\mathrm{DBHi}=\frac{\mathrm{CBH}}{\pi}
$$

The canopy area was measured by the edge length from the vertical plane through the trunk centre to the tip of the branches, at $45^{\circ}$ angles to each other, thus forming eight triangles or subareas. The canopy area (A) was calculated by the equation:

$$
\mathrm{A}=\frac{\Sigma\left(\mathrm{a} \times \mathrm{b} \times \sin 45^{\circ}\right)}{2}
$$

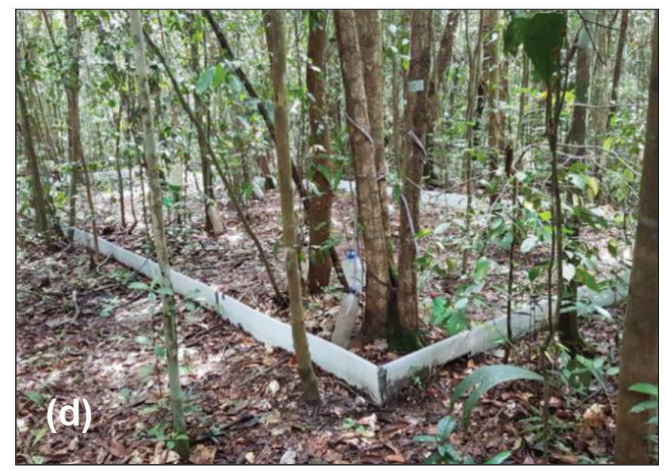

Figure 2 Experimental plots along the forest edge (plots a and b) and in the forest interior (plots c and d)

Table 1 Characteristics of study plots

\begin{tabular}{ccccc}
\hline Plot & Area $\left(\mathrm{m}^{2}\right)$ & No. of trees & Mean height $(\mathrm{m})$ & Relative density $\left(\right.$ trees $\left.\mathrm{m}^{-2}\right)$ \\
\hline 1 & 69.28 & 7 & 3.43 & 0.10 \\
2 & 60.41 & 7 & 6.74 & 0.11 \\
3 & 82.96 & 16 & 6.26 & 0.19 \\
4 & 58.43 & 16 & 5.31 & 0.27 \\
\hline
\end{tabular}


where, $\mathrm{A}\left(\mathrm{m}^{2}\right)$ is the sum of the area of each section, and $\mathrm{a}$ and $\mathrm{b}$ are the lengths $(\mathrm{m})$ of two sections angled at $45^{\circ}$.

\section{Morphological characterisation}

The morphological characterisation of the trunk characteristics of each species were analysed by considering the traits of the bark and trunk:

(1) bark texture: rough or smooth bark surface (Figure 3), according to the characterisation proposed by Nultsch (2000),

(2) trunk inclination: inclined or upright (Melo et al. 2005).

\section{Monitoring stemflow}

Stemflow collectors were assembled with containers and plastic hoses cut crosswise and wound around the trunk to conduct the flow to storage containers (Figure 4). These runoff collectors were installed on trees with a circumference at breast height of $\geq 15 \mathrm{~cm}$.

The stemflow was captured from August 2018 to July 2019, after each rainfall of $>10 \mathrm{~mm}$, in a $500 \mathrm{~mL}$ graduated cylinder. Open rainfall was measured with a rain gauge near plot 1 , in an area without vegetation influence.

\section{Data analysis}

The dendometric variables and total stemflow volumes were subjected to cluster analysis (Euclidean distance and average linkage method), to check the formation of dendometric similarity groups by the construction of dendrograms using IBM SPSS (2020). The variables that significantly influenced cluster formation were identified by analysis of variance, which were later correlated (Pearson) with stemflow volume, within sets with distinct morphological characteristics.

\section{RESULTS AND DISCUSSION}

The circumference at breast height values of the trees in the study area varied from 18 to $82 \mathrm{~cm}$, tree height from 2.5 to $8.5 \mathrm{~m}$, basal area from 0.00 to $0.05 \mathrm{~m}^{2}$, canopy projection area from 1.07 to $67.57 \mathrm{~m}^{2}$ and total stemflow volume from 2.54 to $82.82 \mathrm{~L}$ (Table 2 ). High variability in stemflow volume has been highlighted in several studies (Garcia-Estringana et al. 2010, Honda et al. 2014). Of the total of 46 trees, 28 had rough bark while 18 had smooth bark. A total of 35 trees had inclined trunks and 11, upright trunks.

Considering only the dendometric characteristics and total stemflow volumes, multivariate analysis was carried out to form groups of similar trees in relation to the analysed variables. This resulted in the formation of six clusters (Figure 5). ANOVA was applied $(p \leq 0.05)$ to identify the variables responsible for cluster formation. All variables except tree height influenced the formation of similarity groups (Table 3 ).

The number of trees in each cluster showed two major groups (clusters 1 and 3) which comprised 46.6 and $32.6 \%$ of the trees respectively. An analysis of only the major

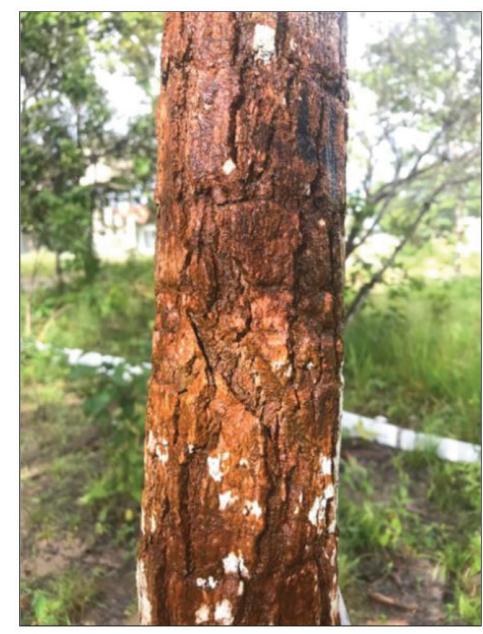

(a)

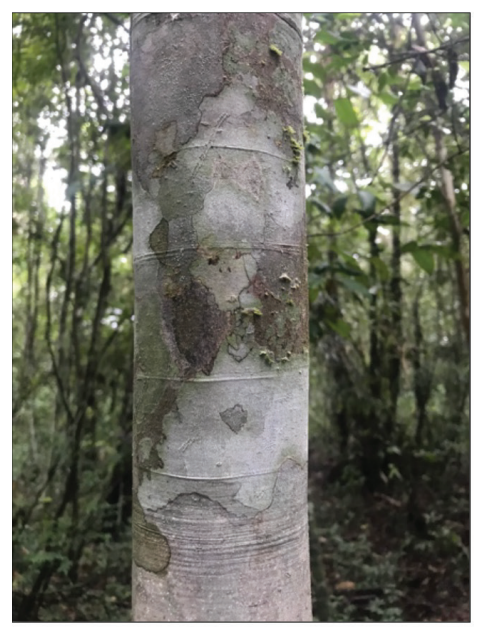

(b)

Figure 3 Bark texture (a) rough and (b) smooth 


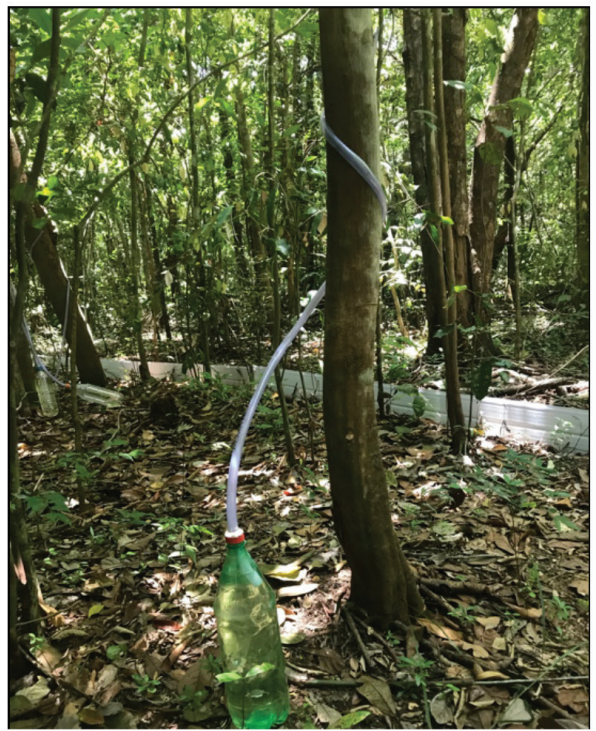

Figure 4 Stemflow collection system

groups showed that $76 \%$ of the trees in group 1 had inclined trunks and $66 \%$ had rough bark texture. Of the trees in group 3 , the percentages were 87 and $66 \%$ respectively. This indicated that the bark microrelief and trunk inclination, together with significant variables, were decisive for the definition of the runoff pattern down tree trunks in the transition forest of the Amazonian savanna. All trees in groups 4 and 5, had smooth and inclined trunks and all trees in group $6 \mathrm{had}$ rough and upright trunks.

The Pearson's correlation analysis showed that there was low correlation between dendometric variables (circumference at breast height, basal area and canopy projection area) with total stemflow volume (Table 4 ). For tree species of the Brazilian Cerrado, Honda et al. (2014) found low correlations between circumference at breast height and basal area and stemflow volume. Circumference at breast height and stemflow volume of tropical forest species were also weakly correlated (Dietz et al. 2006). A significant correlation between stemflow volume and canopy projection area and circumference at breast height was identified by Návar (2011) who studied conifer, oak and shrubs. Crockford and Richardson (2000) reported significant correlation between stemflow and basal area. In invasive species, increased stemflow production was detected by Whitworth-Hulse et al. (2020) as a result of higher basal area and canopy area.

The Person's correlation was performed by grouping trees in relation to morphological characteristics (Table 5). For the tree groups with upright trunks, stemflow volume was strongly correlated with the dendometric characteristics.

Considering only trees with upright trunks, the dendometric characteristics circumference at breast height and basal area had moderate negative correlation with total stemflow volume $(-0.54$ and -0.51 respectively). This indicated that the parameters related to circumference at breast height were not determinants for stemflow. Actual stemflow yield can be computed from a large number of biotic and abiotic variables related to each other in an integrated analysis (Cayuela et al. 2018, Rakestraw et al. 2019). The stemflow component is frequently neglected in water budgeting for trees and shrubs due to its presumed small volume and limited research. Studies of stemflow in shrub species are especially rare. This study focused on stemflow in shrubs and specifically examined its relationship to plant morphology and meteorological factors. Studies that proved the influence of tree size on stemflow production took into account the characteristics of rainfall, among other meteorological factors (Levia et al. 2010). This was not taken into account in our study and the results indicated that size (represented by circumference at breast height) did not influence volumes.

Trees with upright trunks and rough bark, had even higher correlations for circumference at breast height $(-0.83)$ and basal area $(-0.81)$ than individuals with upright trunks, without considering the texture. For trees with upright trunk and smooth bark, only canopy projection area was strongly correlated with stemflow $(0.88)$, indicating that the larger the canopy projection area, the higher the stemflow volume.

The stemflow volume cannot be explained by only one variable but instead by a set of variables. In this study, when the trunk inclination was included in the analysis, the correlation was significant for upright trunk and increased after the inclusion of bark texture. A significant correlation between stemflow and bark roughness as well as for trunk inclination was reported by Honda et al. (2014).

The analysis of mean stemflow volumes of the monitoring period showed that stemflow production from smooth-bark trees was greater $(29.4 \mathrm{~L})$ than trees with rough bark (Table 6). Rough-bark species have greater water retention capacity, generally resulting in a lower stemflow production than smooth-bark species (Brooks 
Table 2 Individual dendometric and morphological characteristics and total stemflow of 46 surveyed trees

\begin{tabular}{|c|c|c|c|c|c|c|c|}
\hline \multirow[t]{2}{*}{ Tree } & \multicolumn{4}{|c|}{ Dendometric characteristic } & \multicolumn{2}{|c|}{ Morphological characteristic } & \multirow{2}{*}{$\begin{array}{c}\text { Total } \\
\text { stemflow } \\
(\mathrm{L})\end{array}$} \\
\hline & $\begin{array}{l}\mathrm{CBH} \\
(\mathrm{cm})\end{array}$ & $\begin{array}{l}\text { Height } \\
(\mathrm{m})\end{array}$ & $\begin{array}{l}\text { Basal area } \\
\left(\mathrm{m}^{2}\right)\end{array}$ & $\begin{array}{l}\text { Canopy projection } \\
\text { area }\left(\mathrm{m}^{2}\right)\end{array}$ & Bark & Trunk & \\
\hline 1 & 27 & 4.20 & 0.01 & 17.17 & Rough & Inclined & 25.55 \\
\hline 2 & 23 & 3.20 & 0.00 & 10.57 & Smooth & Inclined & 15.77 \\
\hline 3 & 24 & 3.90 & 0.00 & 67.45 & Smooth & Inclined & 28.46 \\
\hline 4 & 18 & 2.50 & 0.00 & 3.27 & Rough & Inclined & 3.93 \\
\hline 5 & 30 & 2.80 & 0.01 & 7.36 & Smooth & Inclined & 16.96 \\
\hline 6 & 32 & 3.10 & 0.01 & 10.95 & Smooth & Upright & 5.80 \\
\hline 7 & 61 & 4.30 & 0.03 & 15.69 & Smooth & Upright & 18.79 \\
\hline 8 & 20 & 4.50 & 0.00 & 1.07 & Rough & Upright & 44.43 \\
\hline 9 & 41 & 8.00 & 0.01 & 3.97 & Rough & Upright & 16.17 \\
\hline 10 & 43 & 8.40 & 0.01 & 14.83 & Smooth & Upright & 14.30 \\
\hline 11 & 30 & 6.80 & 0.01 & 2.66 & Rough & Upright & 34.12 \\
\hline 12 & 40 & 7.50 & 0.01 & 10.90 & Rough & Inclined & 12.40 \\
\hline 13 & 29 & 7.10 & 0.01 & 12.10 & Smooth & Inclined & 23.74 \\
\hline 14 & 82 & 4.90 & 0.05 & 25.67 & Rough & Upright & 2.54 \\
\hline 15 & 78 & 8.00 & 0.05 & 43.50 & Rough & Upright & 18.61 \\
\hline 16 & 32 & 7.00 & 0.01 & 5.00 & Rough & Inclined & 53.92 \\
\hline 17 & 30 & 6.50 & 0.01 & 16.11 & Rough & Inclined & 38.34 \\
\hline 18 & 30 & 6.50 & 0.01 & 6.28 & Smooth & Inclined & 24.26 \\
\hline 19 & 26 & 6.50 & 0.01 & 9.22 & Smooth & Inclined & 22.90 \\
\hline 20 & 40 & 8.50 & 0.01 & 23.75 & Rough & Upright & 40.89 \\
\hline 21 & 22 & 5.00 & 0.00 & 8.85 & Rough & Inclined & 51.39 \\
\hline 22 & 19 & 5.00 & 0.00 & 11.18 & Smooth & Inclined & 22.26 \\
\hline 23 & 21 & 4.50 & 0.00 & 12.03 & Smooth & Inclined & 55.11 \\
\hline 24 & 58 & 7.50 & 0.03 & 5.53 & Rough & Inclined & 20.68 \\
\hline 25 & 53 & 7.50 & 0.02 & 3.40 & Rough & Inclined & 19.85 \\
\hline 26 & 33 & 7.50 & 0.01 & 3.40 & Rough & Inclined & 9.00 \\
\hline 27 & 20 & 4.50 & 0.00 & 3.40 & Smooth & Inclined & 21.24 \\
\hline 28 & 33 & 7.00 & 0.01 & 4.89 & Rough & Inclined & 5.50 \\
\hline 29 & 30 & 7.00 & 0.01 & 16.57 & Rough & Inclined & 13.86 \\
\hline 30 & 40 & 7.00 & 0.01 & 11.38 & Rough & Inclined & 50.13 \\
\hline 31 & 34 & 6.00 & 0.01 & 6.62 & Smooth & Inclined & 36.67 \\
\hline 32 & 34 & 6.50 & 0.01 & 9.02 & Smooth & Inclined & 35.30 \\
\hline 33 & 46 & 6.00 & 0.02 & 10.13 & Smooth & Inclined & 76.45 \\
\hline 34 & 39 & 7.50 & 0.01 & 7.51 & Rough & Inclined & 25.33 \\
\hline 35 & 28 & 6.00 & 0.01 & 14.44 & Smooth & Upright & 20.58 \\
\hline 36 & 28 & 3.50 & 0.01 & 4.90 & Rough & Inclined & 22.54 \\
\hline 37 & 28 & 6.00 & 0.01 & 8.38 & Smooth & Inclined & 82.82 \\
\hline 38 & 23 & 7.00 & 0.00 & 9.28 & Rough & Inclined & 28.62 \\
\hline 39 & 22 & 5.50 & 0.00 & 13.86 & Rough & Inclined & 9.89 \\
\hline 40 & 19 & 3.00 & 0.00 & 12.00 & Rough & Inclined & 10.73 \\
\hline 41 & 44 & 4.00 & 0.02 & 7.11 & Rough & Inclined & 23.35 \\
\hline 42 & 21 & 5.00 & 0.00 & 15.12 & Rough & Inclined & 4.01 \\
\hline 43 & 25 & 4.00 & 0.00 & 3.62 & Rough & Inclined & 15.18 \\
\hline 44 & 51 & 6.00 & 0.02 & 28.20 & Smooth & Inclined & 7.36 \\
\hline 45 & 49 & 4.00 & 0.02 & 9.37 & Rough & Inclined & 27.12 \\
\hline 46 & 70 & 5.00 & 0.04 & 40.65 & Rough & Upright & 5.90 \\
\hline
\end{tabular}

$\mathrm{CBH}=$ circumference at breast height; the null values of basal area occurred due to the use of only two decimal places, so that some extremely low values appear as zero in the analysis 


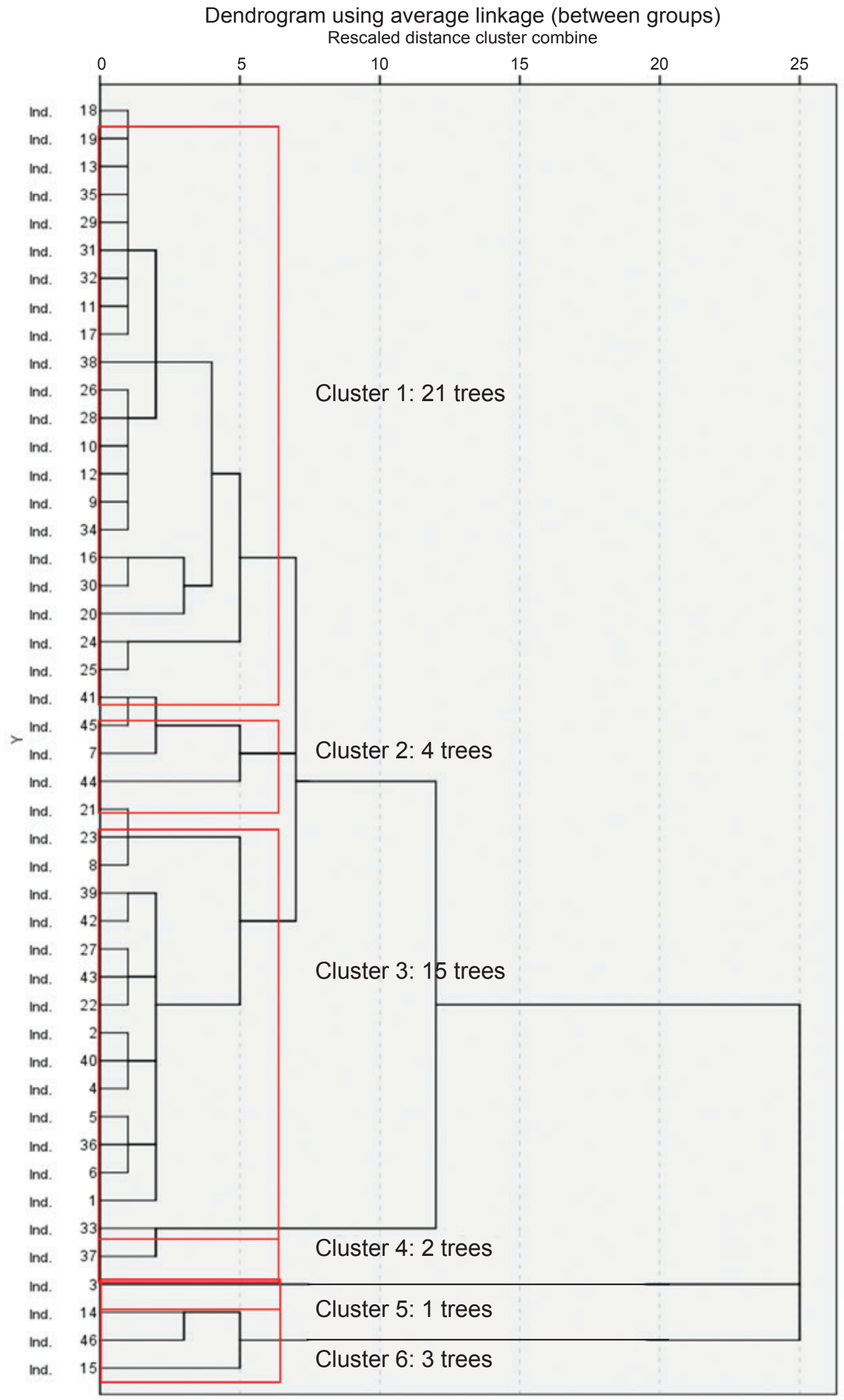

Figure 5 Similarity dendrogram for dendometric characteristics of the 46 trees studied 
Table 3 ANOVA results $(\mathrm{p} \leq 0.05)$ of the variables responsible for cluster formation

\begin{tabular}{|c|c|c|c|c|c|c|}
\hline \multirow{2}{*}{ Variable } & \multicolumn{2}{|c|}{ Cluster } & \multicolumn{2}{|c|}{ Error } & \multirow[t]{2}{*}{ F ratio } & \multirow{2}{*}{ Significance } \\
\hline & $\begin{array}{c}\text { Mean } \\
\text { square }\end{array}$ & $\mathrm{df}$ & $\begin{array}{c}\text { Mean } \\
\text { square }\end{array}$ & $\mathrm{df}$ & & \\
\hline Circumference at breast height $(\mathrm{cm})$ & 1781.9 & 5 & 42.8 & 40 & 41.6 & 0.000 \\
\hline Tree height (m) & 4.2 & 5 & 2.6 & 40 & 1.6 & 0.173 \\
\hline Basal area $\left(\mathrm{m}^{2}\right)$ & .001 & 5 & .000 & 40 & 30.2 & 0.000 \\
\hline Canopy projection area $\left(\mathrm{m}^{2}\right)$ & 1015.6 & 5 & 37.4 & 40 & 27.2 & 0.000 \\
\hline Total stemflow $(\mathrm{L})$ & 2472.5 & 5 & 56.6 & 40 & 43.7 & 0.000 \\
\hline
\end{tabular}

Table 4 Pearson's correlation coefficients between dendometric variables and stemflow

\begin{tabular}{lccc}
\hline & CBH & BA & CPA \\
\hline Total stemflow & -0.17 & -0.21 & -0.14 \\
\hline
\end{tabular}

$\mathrm{CBH}=$ circumference at breast height, $\mathrm{BA}=$ basal area, $\mathrm{CPA}=$ canopy projection area

Table 5 Pearson's correlation coefficients between dendometric variables and stemflow for different morphological characteristics

\begin{tabular}{llcccc}
\hline & & Rough bark & Smooth bark & Upright trunk & Inclined trunk \\
\hline \multirow{3}{*}{ Rough bark } & $\mathrm{TStF} \times \mathrm{Cap}$ & -0.21 & - & -0.83 & -0.01 \\
& $\mathrm{TStF} \times \mathrm{BA}$ & -0.26 & - & -0.81 & -0.08 \\
& $\mathrm{TStF} \times \mathrm{CPA}$ & -0.20 & - & -0.41 & -0.15 \\
\hline \multirow{3}{*}{ Smooth bark } & $\mathrm{TStF} \times \mathrm{Cap}$ & - & -0.06 & 0.29 & 0.12 \\
& $\mathrm{TStF} \times \mathrm{BA}$ & - & -0.08 & 0.33 & 0.07 \\
& $\mathrm{TStF} \times \mathrm{CPA}$ & - & -0.12 & 0.88 & -0.14 \\
\hline \multirow{5}{*}{ Upright trunk } & $\mathrm{TStF} \times \mathrm{Cap}$ & - & - & -0.54 & - \\
& $\mathrm{TStF} \times \mathrm{BA}$ & - & - & -0.51 & - \\
& $\mathrm{TStF} \times \mathrm{CPA}$ & - & - & -0.29 & - \\
\hline \multirow{5}{*}{ Inclined trunk } & $\mathrm{TStF} \times \mathrm{Cap}$ & - & - & - & -0.03 \\
& $\mathrm{TStF} \times \mathrm{BA}$ & - & - & - & -0.08 \\
& $\mathrm{TStF} \times \mathrm{CPA}$ & - & - & - & -0.09 \\
\hline
\end{tabular}

$\mathrm{CBH}=$ circumference at breast height, $\mathrm{BA}=$ basal area, $\mathrm{CPA}=$ canopy projection area, $\mathrm{TStF}=$ total stemflow

et al. 2012). In a measurement of the bark microrelief of two tree species, Van Stan and Levia (2009) identified bark roughness as the factor that determined stemflow volume. The authors found that species with smooth bark produced higher stemflow volumes even after smaller rainfall events. The stemflow production in more rugged classes is lower, due to the greater water storage capacity in the bark (Levia et al. 2010, Carlyle-Moses \& Price 2006, Liang et al. 2009). Trees with smooth bark and also upright trunk, had the lowest mean stemflow volume (14.9 L). Canopy projection area was strongly correlated with stemflow (0.88), indicating that the larger the canopy area, the higher the stemflow.

Honda et al. (2014) found that the most efficient trees in stemflow production were trees with smooth bark and upright trunks. This contrasts with the pattern observed in this study whereby mean stemflow volume was highest $(33.5 \mathrm{~L})$ from trees which had smooth bark and inclined trunks. In a highly heterogeneous 
Table 6 Mean stemflow volume (L) for trees with different morphological characteristics

\begin{tabular}{lcccc}
\hline & Rough bark & Smooth bark & Upright stem & Inclined stem \\
\hline Rough bark & 22.6 & - & 26.12 & 21.7 \\
Smooth bark & - & 29.4 & 14.9 & 33.5 \\
Upright stem & - & - & 21.6 & - \\
Inclined stem & - & - & - & 26.3 \\
\hline
\end{tabular}

environment, as that of a tropical forest, stemflow volume of inclined trees will increase when additional stemflow from neighbouring trees drips directly onto the inclined trunk.

\section{CONGLUSIONS}

Circumference at breast height, basal area, canopy projection area and stemflow are important determinants for the formation of similar tree groups. No correlation was observed between dendometric characteristics and stemflow. However, when trees were grouped according to their morphological characteristics, significant correlations were identified between basal area and circumference at breast height and stemflow from trees with an upright trunk and rough bark and between canopy projection area and stemflow from smooth-bark trees. Mean stemflow volumes were higher from smooth trees. However, when the variable trunk inclination was taken into consideration, the mean values were lowest for upright and highest for inclined trunks, demonstrating the importance of this variable for stemflow production.

\section{REFERENCES}

Brooks KN, Folliott PF \& Magner JA. 2012. Watershed management issues. Pp 427-461 in Hydrology and the Management of Watersheds. Fourth edition. John Wiley \& Sons Inc., Ames.

Burbano-Garcés ML, Figueiroa-Casas A \& Peña M. 2014. Bulk precipitation and stemflow deposition of $\mathrm{N}_{-} \mathrm{NH}_{4}^{+}$, $\mathrm{N}-\mathrm{NH}_{3}$ and $\mathrm{N}^{-\mathrm{NO}_{3}}$ in Andean Forest. Journal of Tropical Forest Science 26: 446-457.

Carlyle-Moses DE \& Price AG. 2006. Growing-season stemflow production within a deciduous forest of Southern Ontario. Hydrological Processes 20: 36513663. https://doi.org/10.1002/hyp.6380

Carlyle-Moses DE, LidA SI, Germer S et Al. 2018. Expressing stemflow commensurate with its ecohydrological importance. Advances in Water Resources 121: 472-479. https://doi.org/10.1016/j.advwatres.2018.08.015

Cayuela C, Llorens P, Sánchez-Costa E, Levia DF \& Latron J. 2018. Effect of biotic and abiotic factors on inter- and intra-event variability in stemflow rates in oak and pine stands in a Mediterranean mountain area. Journal of Hydrology 560: 396-406. https:/ / doi. org/10.1016/j.jhydrol.2018.03.050

Crockford RH \& Richardson DP. 2000. Partitioning of rainfall into throughfall, stemflow and interception: effect of forest type, groundcover and climate. Hydrological Processes 14: 29032920. https://doi.org/10.1002/1099$1085(200011 / 12) 14: 16 / 17<2903:$ :AID HYP126>3.0.CO;2-6

Dietz J, Hölscher D, Leushner C \& Hendrayanto. 2006. Rainfall partitioning in relation to forest structure in differently managed montane forest stands in Central Sulawesi, Indonesia. Forest Ecology and Management 237: 170-178. https://doi.org/10.1016/j. foreco.2006.09.044

Drummond JA. 2004. Atlas das Unidades de Conservação do Estado do Amapá. MMA/IBAMA-AP; GEA/SEMA, Macapá.

Frost EE \& LeVIA DF. 2014. Hydrologic variation of stemflow yield across co-occurring dominant canopy trees of varying mortality. Ecohydrology 7: 760-770. https:// doi.org/10.1002/eco.1397

Garcia-Estringana P, Alonso-Blázquez N \& Alegre J. 2010. Water storage capacity, stemflow and water funneling in Mediterranean shrubs. Journal of Hydrology 389: 363-372. https://doi.org/10.1016/j. jhydrol.2010.06.017

Giglio JN \& KobIYAma M. 2013. Interceptação da chuva: uma revisão com ênfase no monitoramento em florestas Brasileiras. Revista Brasileira de Recursos Hidricos 18: 297-317. https://doi.org/10.21168/rbrh.v18n2. p297-317

Honda EA, Mendonça AH \& Durigan G. 2014. Factors affecting the stemflow of trees in the Brazilian Cerrado. Ecohydrology 8: 1351-1362. https://doi. org/10.1002/eco.1587

Levia DF, Van Stan JTS \& Mage S. 2010. Temporal variability of stemflow volume in a beech-yellow poplar forest in relation to tree species and size. Journal of Hydrology 380: 112-120. https://doi.org/10.1016/j. jhydrol.2009.10.028

LeVia DF \& Germer S. 2015. A review of stemflow generation dynamics and stemflow-environment interactions in forests and shrublands. Reviews of Geophysic 53: 673-714. https://doi.org/10.1002/2015RG000479

Liang WL, Kosugi K \& Mizuyama T. 2009. Characteristics of stemflow for tall stewartia (Stewartia monadelpha) growing on a hillslope. Hydrology 378: 168-178. https://doi.org/10.1016/j.jhydrol.2009.09.027 
Marin C, Bouten W \& Evink J. 2000. Gross rainfall and its partitioning into throughfall, stemflow and evaporation of intercepted water in four forest ecosystems in western Amazonia. Journal of Hydrology 237: 40-57. https://doi.org/10.1016/s00221694(00)00301-2

Melo VS, SÁ TDA \& Moller MRF. 2005. Escoamento pelo tronco (EPT) em floresta primária explorada seletivamente na Amazônia Oriental. Revista de Ciências Agrárias 44: 97-106.

Metzger JC, Schumacher J, Lange M \& Hildebrandt A. 2019. Neighbourhood and stand structure affect stemflow generation in a heterogeneous deciduous temperate forest. Hydrology and Earth System Sciences 23: 4433-4452. https://doi.org/10.5194/hess-234433-2019

Munishi T \& SHEAR TH. 2005. Rainfall interception and partitioning in afromontane rain forests of the eastern arc mountains, Tanzania: implications for water conservation. Journal of Tropical Forest Science 17: 355-365.

NÁVAR J. 2011. Stemflow variation in Mexico's northeastern forest communities: its contribution to soil moisture content and aquifer recharge. Journal of Hydrology 408: 35-42.https://doi.org/10.1016/j. jhydrol.2011.07.006

Nobre AD. 2014. The Future Climate of Amazonia-Scientific Assessment Report. Articulación Regional Amazónica, São José dos Campos.

Nobre CA, Oyama MD, Oliveira GS, Marengo Ja \& Salati E. 2004. Impact of Climate Change Scenarios for 2010 on the Biomes of South America. First International CLIVAR Conference. 21-25 June 2004, Baltimore. http:/ / www.clivar2004.org.

Nultsch W. 2000. Botânica Geral. Artmed, Porto Alegre.

Rakestraw E, Jacobson S, Gurian PL \& Montalto FA. 2019. Quantification of stemflow in three isolated shrub species in an urban environment. Frontiers in Built Environment 5: 1-8. https://doi.org/10.3389/ fbuil.2019.00110
Staelens JA, Schrijver AD, Verheyen K \& Verhoest NeG. 2008. Rainfall partitioning into throughfall, stemflow, and interception within a single beech (Fagus sylvatica L.) canopy: influence of foliation, rain event characteristics, and meteorology. Hydrological Processes 22: 33-45. https://doi.org/10.1002/hyp.6610

VAn Stan JT \& LeVIa DF. 2009. Inter- and intraspecific variation of stemflow production from Fagus grandifolia Ehrh. (American beech) and Liriodendron tulipifera L. (yellow poplar) in relation to bark microrelief in the eastern United States. Ecohydrology 3: 11-19. https://doi.org/10.1002/eco.83

Van Stan JT, Lewis ES, Hildebrandt A, Rebmann C \& Friesen J. 2016. Impact of interacting bark structure and rainfall conditions on stemflow variability in a temperate beech-oak forest, central Germany. Journal Hydrological Sciences 61: 2071-2083. https:/ / doi.org/ 10.1080/02626667.2015.1083104

Van Stan JT \& Friesen J. 2020. Precipitation partitioning, or to the surface and back again: historical overview of the first process in the terrestrial hydrologic pathway. Pp 1-16 in Van Stan JT et al. (eds) Precipitation Partitioning by Vegetation: A Global Synthesis. Springer, Cham.

Whitworth-Hulse JI, Magliano PN, Zeballos SR, Gurvich DE, Spalazzi MF \& Esteban K. 2020. Advantages of rainfall partitioning by the global invader Ligustrum lucidum over the dominant native Lithraea molleoides in a dry forest. Agricultural and Forest Meteorology 209: 108013

YANG X, ShaO M \& WeI X. 2018. Stemflow production differ significantly among tree and shrub species on the Chinese Loess Plateau. Journal of Hydrology 568: 427436. https://doi.org/10.1016/j.jhydrol.2018.11.008

Zhang Y, Wang X, Hu R \& Pan Y. 2013. Stemflow in two xerophytic shrubs and its significance to soil water and nutrient enrichment. Ecological Research 28: 567579. https://doi.org/10.1007/s11284-013-1046-9 